\title{
Australians' Financial Wellbeing and Household Debt: A Panel Analysis
}

\author{
Muhammad S. Tahir *(D) and Abdullahi D. Ahmed \\ School of Accounting, Information Systems, and Supply Chain, College of Business and Law, RMIT University, \\ Melbourne 3000, Australia; abdullahidahir.ahmed@rmit.edu.au \\ * Correspondence: muhammad.tahir@rmit.edu.au
}

check for updates

Citation: Tahir, Muhammad S., and Abdullahi D. Ahmed. 2021

Australians' Financial Wellbeing and Household Debt: A Panel Analysis. Journal of Risk and Financial Management 14: 513. https:// doi.org/10.3390/jrfm14110513

Academic Editor: Mark Harris

Received: 27 September 2021

Accepted: 21 October 2021

Published: 26 October 2021

Publisher's Note: MDPI stays neutral with regard to jurisdictional claims in published maps and institutional affiliations.

Copyright: (c) 2021 by the authors. Licensee MDPI, Basel, Switzerland. This article is an open access article distributed under the terms and conditions of the Creative Commons Attribution (CC BY) license (https:// creativecommons.org/licenses/by/ $4.0 /)$.

\begin{abstract}
An excess of everything is bad". This famous old proverb fits well with the current condition of Australian household debt that is continuously rising. Research in Australia's household indebtedness is scarce and strategies to control the rising household debt remain contentious. The government of Australia has introduced financial literacy and financial capability measures to help control the rising household debt. Given that the literature highlights the importance of improving financial wellbeing, we analyse if financial wellbeing is a factor, which could be relevant to the reduced household debt. We use the Household, Income and Labour Dynamics in Australia panel survey in our analysis and find that improved financial wellbeing is associated with the reduced debttaking behaviour of Australians. Our robust analysis confirms our findings. Finally, our empirical results suggest that improving households' perception of their personal financial situation can bring improvement in their financial decisions, including the decision to take on debt.
\end{abstract}

Keywords: household debt; financial wellbeing; financial satisfaction; Australia; HILDA

\section{Introduction}

Over the last three decades, many countries, including Australia, have been facing a swift growth in household debt (Meng et al. 2013). Since 2002, the mean value of household debt in Australia increased by 87 per cent, whereas the mean value of assets grew only by 42 per cent (Wilkins 2016, p. 10). Moreover, Figure 1 shows the Australian household debt to income ratio from 2009 to 2018, depicting that the household debt-to-income ratio was 159 in 2009 and surged to 188 in 2018. Within these ten years, a slight decline was noted from 2010 to 2012. However, the ratio increased by an increasing rate from 2012 to 2017. These statistics have sounded the tocsin thus loudly that a report from the Australian Securities and Investment Commission (ASIC 2017, p. 5) noted, "the ratio of household debt to household income is at a record high". Research conveys that debt taken beyond means can cause health problems such as anxiety and depression, mental health issues, drug addiction, heart problems, or migraine headaches (Berger et al. 2016; Jarl et al. 2015; Meltzer et al. 2010; Richardson et al. 2013; Sweet et al. 2013; Turunen and Hiilamo 2014). Given the negative consequences of rising household debt, it is important to identify factors relevant to the reduced debt-taking behaviour of Australians.

Recent research highlights the importance of improving financial wellbeing (Tahir et al. 2021). Financial wellbeing refers to an individual's perception of the personal financial situation (Brüggen et al. 2017). The emerging concept of financial wellbeing is a part of the financial planning subject that is gaining researchers' attention globally (Altfest 2004; Liao and Xiao 2014; McKeown et al. 2014). The empirical research of Garðarsdóttir and Dittmar (2012) in Finland analysed the association between materialism and financial wellbeing. They concluded that those with a more materialistic mindset have more financial worries, worse money-management skills, a greater tendency to compulsive buying, and more debt. Similarly, the empirical findings of Donnelly et al. (2012) show that a better perception of personal financial situation leads to an increase in savings and reduction in debt burden. 
In addition, they find an association between better financial decision-making ability and improved financial wellbeing status. As debt taking is a part of households' financial decisions, extant research finds that improving financial knowledge is associated with reduced credit card debt-taking behaviour (Tahir et al. 2020). However, the research of Tahir et al. (2020) is limited to a cross-sectional survey. In this study, we expand on the findings of Tahir et al. (2020) by using panel data and address the following research question:

To what extent does financial wellbeing relate to reduced debt-taking behaviour?

To meet the objective of this research, we use the Household, Income and Labour Dynamics in Australia (HILDA) survey. The findings show that improving households' perception of their personal financial situation can improve their financial decisions, including the decision to take on debt. The research has policy implications, suggesting that improving financial wellbeing exerts both the short-run and long-run benefits.

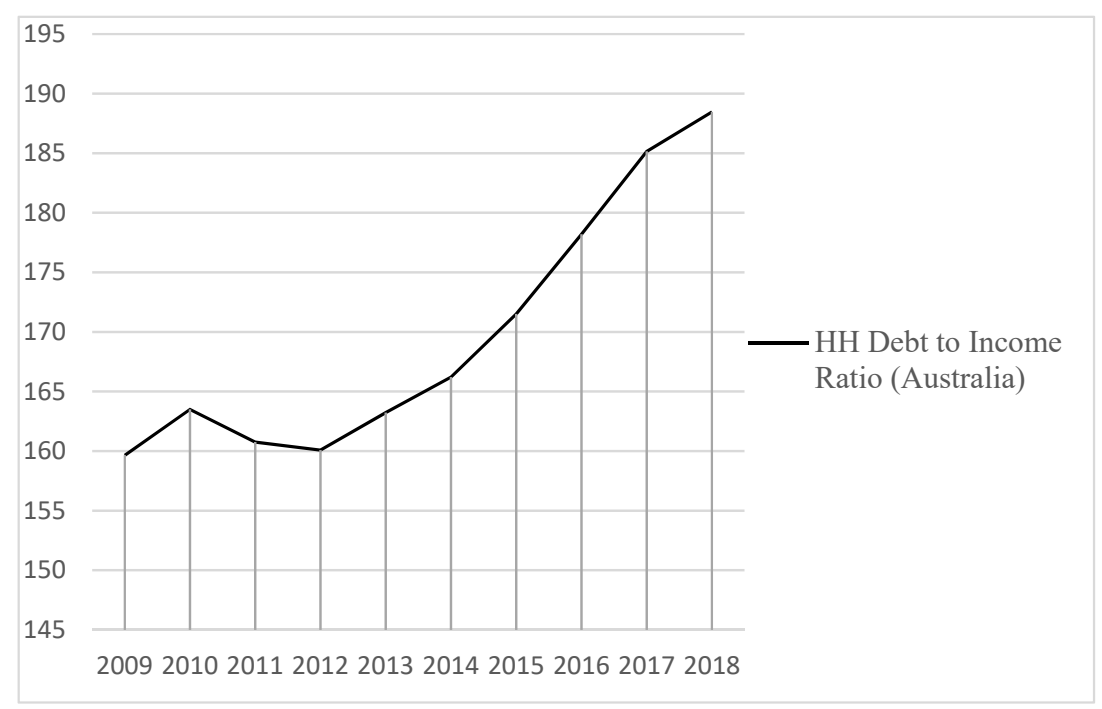

Figure 1. Household debt to income ratio of Australians from 2009 to 2018. Data of the figure is adapted from the Reserve Bank of Australia (2019).

The next section of this paper reviews relevant prior studies followed by an explanation of the dataset and method of data analysis. Next, we present empirical results, discuss and conclude the results, and state the directions for future research.

\section{Literature Review}

\subsection{Financial Wellbeing}

As the concept of financial wellbeing is still an infant in the field of consumer finance, researchers measure financial wellbeing differently. Some research defines financial wellbeing subjectively (Brüggen et al. 2017; Xue et al. 2019), while others define it objectively (Chu et al. 2017; Cifuentes et al. 2016). Xiao and O'Neill (2018) contend that one can achieve higher levels of financial wellbeing if they have the appropriate financial knowledge and perform desirable financial behaviour. Kempson et al. (2017) portray financial wellbeing as the ability not only to meet current financial needs easily but also to have such capacity to uphold this in the future. Brown and Gray (2016) argue that financial wellbeing is best measured using two concepts, that are subjective prosperity (Siahpush et al. 2007) and financial satisfaction (Headey and Wooden 2004). Vlaev and Elliott (2014) define financial wellbeing as having greater control over money.

Brüggen et al. (2017, p. 229) theoretically conceptualise financial wellbeing as "the perception of being able to sustain current and anticipated desired living standards and financial freedom". This definition is subjective as it endorses the view that financial wellbeing is what people perceive about their financial condition. People with similar objective characteristics (such as income level, assets, and net wealth) may feel differently about their financial conditions. Recent research supports the subjective measurement of 
financial wellbeing and overshadows the significance of objective measures (Brüggen et al. 2017; Utkarsh et al. 2020; Xue et al. 2019).

Researchers contend that a consumer's perception of their financial condition is worthwhile to consider, as it reflects the level of engagement with their financial matters (Netemeyer et al. 2018). Higher levels of financial wellbeing are associated with lower financial stress (Choi et al. 2020), positive overall wellbeing (Netemeyer et al. 2018), and positive financial behaviour (Brüggen et al. 2017; Xue et al. 2019).

\subsection{Financial Wellbeing in the Australian Context}

Given the significance of financial wellbeing and its positive relation with overall wellbeing (Netemeyer et al. 2018), it is pertinent to find the association between improved financial wellbeing and reduced household debt. Some recent research studies and surveys measure financial wellbeing in Australia. A study by Muir et al. (2017) researched financial wellbeing using qualitative interviews and a quantitative survey to ascertain how financial wellbeing can be measured and what factors influence financial wellbeing in an Australian context. They found three dimensions of financial wellbeing: (a) meeting expenses by saving for the future, (b) being in control, and (c) feeling financially secure. Their findings show that positive attitude towards money strongly influences financial wellbeing. A survey led by the Australia and New Zealand Banking Group (ANZ Bank 2018) showed that individuals improve their overall financial wellbeing when they actively save and avoid borrowing. Haisken-DeNew et al. (2019) presented three categories of young Australians and separately define financial wellbeing for each category. Their categories of young Australians include children, adolescents, and emerging adults.

While there exist institutions-led financial wellbeing surveys and research in Australia, little peer-reviewed empirical research is published exploring factors associated with the financial wellbeing of Australian consumers. Xue et al. (2019) surveyed Australians aged above 54 to find if financial literacy and consumption pattern are related to financial wellbeing. Their empirical results show that financial literacy and the ability to meet essential and non-essential consumption needs help improving financial wellbeing. Gerrans et al. (2014) showed separate predictors of financial satisfaction (a component of financial wellbeing (Xiao and $\mathrm{O}^{\prime}$ Neill 2018)) for females and males. According to the results of Gerrans et al. (2014), the financial satisfaction of females is influenced by financial status, whereas the financial satisfaction of males is influenced by financial knowledge. They also contend that financial satisfaction is a direct predictor of overall wellbeing. In another Australian study, Brown and Gray (2016) found that financial wellbeing is positively associated with the levels of net wealth and assets, while levels of debt negatively relate to the financial wellbeing of Australians. Unlike prior studies of the Australian context, we seek to find if improved financial wellbeing is associated with reduced debt-taking behaviour.

\section{Data}

According to Campbell (2006), if a researcher wishes to use a dataset to analyse household finance empirically, it should have at least five features. These five features are: collecting the detail of household wealth and categorising it into sub-parts, these sub-parts must represent an asset classification, the dataset must represent a true sample of the whole population, accuracy-level must be high, and the data must be collected repeatedly on regular intervals (Wilkins 2016).

Until 2000, there was no dataset in Australia, which could represent such characteristics (Wilkins 2016). Since 2001, Australia has been equipped with a rich set of data called the HILDA survey. This dataset has met the requirements of Campbell (2006) as quoted by Wilkins (2016, p. 6): "It is, by design, representative of the Australian population; it produces a comprehensive measure of each household's wealth, in total and by component; and household wealth data has been collected from the same households every four years since 2002."

HILDA is a household panel survey (Richardson 2013). The survey of each year is called a "wave". HILDA has a high response rate-66 per cent in the first wave. Under 
HILDA, the same families are surveyed each year with a retention rate of 96.2 per cent in wave 18 (Summerfield et al. 2019). The authorities collected data of wave 18 in 2018 and granted access in 2020. Wave 18 contains 17,434 persons interviewed from 9639 households across Australia. The HILDA user manual lists the number of persons who responded to each wave since its start (Summerfield et al. 2019, pp. 6-7).

Researchers have been using this rich dataset for empirical analyses since its start in 2001 (Wilkins 2016; Wooden et al. 2002; Wooden and Watson 2007). HILDA has been able to produce hundreds of nationally representative research works (Richardson 2013). As HILDA is not limited to a specific topic, it has been able to produce multi-disciplinary analyses. Similar to the other disciplines, it has contributed to the knowledge of social sciences as well. The literature of personal and household finance has also been able to obtain a sheer knowledge through the empirical analyses of HILDA survey (several examples include: Ambrey and Fleming (2014), Brown and Gray (2016), Cobb-Clark and Ribar (2012), Cobb-Clark et al. (2016), Gong and Kendig (2018), Headey and Wooden (2004), Headey (2008), Kristoffersen (2017), West and Worthington (2019), Wilkins and Wooden (2009), and many others). Thus, the current study also claims to contribute to the knowledge of behavioural, personal, and household finance by employing data from the HILDA survey.

HILDA has a special wealth module, which collects personal and household wealth data every four years since 2002 (Wilkins 2016). This special wealth module asks people if they currently do or do not hold different loans, including bank loans, investment loans, car loans, student loans, and other types of loans. Table 1 presents the loan types and their items in wave 18 only.

Table 1. Detail of the items relating to debt-taking behaviour (wave 18).

\begin{tabular}{|c|c|c|c|c|}
\hline Variable & Item & Response & Frequency & Valid Percent \\
\hline \multirow{3}{*}{ Unpaid bills } & \multirow{3}{*}{ Do you have any unpaid personal bills now overdue? } & No & 16,621 & 95.50 \\
\hline & & Yes & 784 & 4.50 \\
\hline & & Missing & 29 & \\
\hline \multirow{3}{*}{ Car loan } & \multirow{3}{*}{ Do you currently hold a loan to buy a car? } & No & 15,560 & 89.49 \\
\hline & & Yes & 1828 & 10.51 \\
\hline & & Missing & 46 & \\
\hline \multirow{3}{*}{ Loan from friends } & \multirow{3}{*}{$\begin{array}{l}\text { Do you currently hold a loan from friends or family not living in } \\
\text { this household? }\end{array}$} & No & 17,043 & 98.03 \\
\hline & & Yes & 342 & 1.97 \\
\hline & & Missing & 49 & \\
\hline \multirow{3}{*}{ Student loan } & \multirow{3}{*}{ Do you currently hold a student loan? } & No & 14,968 & 86.12 \\
\hline & & Yes & 2413 & 13.88 \\
\hline & & Missing & 53 & \\
\hline \multirow{3}{*}{ Hire purchase loan } & \multirow{3}{*}{ Do you currently hold a hire purchase loan/agreement? } & No & 17,168 & 98.77 \\
\hline & & Yes & 214 & 1.23 \\
\hline & & Missing & 52 & \\
\hline \multirow{3}{*}{ Investment loan } & \multirow{3}{*}{ Do you currently hold an investment loan? } & No & 17,163 & 98.71 \\
\hline & & Yes & 225 & 1.29 \\
\hline & & Missing & 46 & \\
\hline \multirow{3}{*}{ Loan from lenders } & \multirow{3}{*}{ Do you currently hold a loan from other lenders such as solicitors? } & No & 17,190 & 98.87 \\
\hline & & Yes & 197 & 1.13 \\
\hline & & Missing & 47 & \\
\hline \multirow{3}{*}{ Bank loan } & \multirow{3}{*}{$\begin{array}{l}\text { Do you currently hold any other personal loan from a bank or } \\
\text { financial institution? }\end{array}$} & No & 16,403 & 94.34 \\
\hline & & Yes & 984 & 5.66 \\
\hline & & Missing & 47 & \\
\hline
\end{tabular}


Next, all the debt types are combined to form one variable. Table 2 shows that all those respondents who hold at least one type of loan are combined into one category of "yes", whereas the other category "no" contains all the respondents who do not have any type of loan. Hence, debt-taking behaviour is a dichotomous dependent variable of the study, coded " 0 " for category "no" and " 1 " for category "yes". Those who fall in the latter category has debt-taking behaviour.

Table 2. Detail of the combined variable "debt-taking behaviour" (wave 18).

\begin{tabular}{ccc}
\hline Description & Frequency & Valid Percent \\
\hline Currently does not hold any type of loan [0] & 11,751 & 67.76 \\
Currently holds at least one type of loan [1] & 5592 & 32.24 \\
Missing responses & 91 & \\
Total & $\mathbf{1 7 , 4 3 4}$ & \\
\hline
\end{tabular}

HILDA added a personal loan survey in the wealth module in 2006. Currently, four waves contain responses on personal loans: wave 6, wave 10, wave 14, and wave 18 . Responses to these four waves are merged to make it a panel dataset. In the next step, we clean and filter the panel dataset and retain only those respondents who responded to our key variables in the four waves. This step omits the missing responses and creates a balanced panel for empirical analysis. Table 3 displays the summary statistics of the balanced panel.

Table 3. Summary statistics of the balanced panel.

\begin{tabular}{ccccc}
\hline Wave & Frequency & Age & Females & Take on Debt \\
\hline 6 & 5113 & $15-85$ & $54 \%$ & $26.50 \%$ \\
10 & 5113 & $19-89$ & $54 \%$ & $26.25 \%$ \\
14 & 5113 & $23-93$ & $54 \%$ & $22.12 \%$ \\
18 & 5113 & $27-97$ & $54 \%$ & $18.58 \%$ \\
\hline
\end{tabular}

Financial wellbeing is measured using two subjective items. Brown and Gray (2016) have used these items to measure financial wellbeing. The first item relates to subjective prosperity, that is, given your current needs and financial responsibilities, would you say that you and your family are? There were six options available to the respondent, from prosperous to poor. To make this item consistent with other variables of this study, we reverse the scale of this item from poor to prosperous. The second item relates to financial satisfaction, that is, show your satisfaction level with your current financial situation? There were 11 options available to respondents from " 0 " for totally dissatisfied to " 10 " for totally satisfied.

Because subjective prosperity and financial satisfaction were measured on different scales, we standardised and combined the financial wellbeing items using the z-score methodology (Kesavayuth et al. 2018, 2020). In the empirical analysis of this paper, the standardised financial wellbeing scores will be used.

\section{Methodology}

Two types of models that are usually generated in a panel data analysis are the random-effects model and the fixed-effects model. "Fixed-effects models treat the effect size parameters as fixed but unknown constants to be estimated and usually (but not necessarily) are used in conjunction with assumptions about the homogeneity of effect parameters" (Hedges and Vevea 1998, p. 486). Furthermore, fixed-effects models exclude those respondents from the statistical analysis who do not change their response over time. In addition, the structure of the fixed-effects model allows the observed predictors to correlate with $v$. Conversely, "random-effects models treat the effect size parameters as if they were a random sample from a population of effect parameters and estimate 
hyperparameters (usually just the mean and variance) describing this population of effect parameters" (Hedges and Vevea 1998, p. 486). Moreover, unlike fixed-effects models, random-effects models include all the respondents in the statistical analysis whether they change their responses over time or not. In addition, the structure of the random-effects model does not allow the observed predictors to correlate with $v$.

Both models are widely used in panel data analyses. However, the choice between both is based on the researchers' assumptions and the structure of their specific model. Researchers often use the Hausman test to choose between both models (Hausman 1978). According to Bell et al. (2019), the Hausman test is not a test to choose between both models. Rather, it is only a test of whether the within and between effects are different. In many cases, the Hausman test allows using fixed-effects estimates instead of random-effects estimates (Bell et al. 2019). However, the problem occurs when the within variation is too small, which may invalidate the asymptotical normality assumption of the fixed-effects estimates (Hahn et al. 2011). As the fixed-effects model drops the observations where the person does not change the response across the waves, the sample size dramatically diminishes and may provide flawed results.

As the fixed-effects model drops a large number of responses reflecting a small sample size, we choose to use the random-effects model in further empirical analyses. In addition, the recent literature does not support the recommendations of the Hausman test to choose between the fixed-effects and random-effects model (Bell et al. 2019). Instead, data with a small "within variation" are highly recommended to employ the random-effects model (Hahn et al. 2011; Kesavayuth et al. 2020). Hunter and Schmidt (2000) also prefer the random-effects model over the fixed-effects model in social science research. Therefore, a random-effects model is a better choice in the case of this paper.

\section{Estimation Results}

For the purpose of showing the within and between components of financial wellbeing and the transition probabilities of financial wellbeing, the financial wellbeing variable is transformed into a dichotomous variable, coded zero if the mean value is below zero (representing relatively lower levels of financial wellbeing) and coded one if the mean value is above zero (representing relatively higher levels of financial wellbeing).

Table 4 conveys the within and between components of two main variables, debttaking behaviour and financial wellbeing. The overall statistics summarise the person-years results. Out of 20,452 person-years, 15,674 did not have debt, while 4778 had debt. The "between" statistics summarise the data in terms of the respondents, showing that 4869 respondents never had debt, while 2445 had debt, a total of 7314 having either. Next, the "within" per cent shows the fraction of the time a respondent had debt. Conditional on a respondent ever having a " 0 " (not taking on debt) response, 80.48 per cent of their observations have a " 0 " response. Likewise, conditional on a respondent ever having a " 1 " (taking on debt) response, 48.85 per cent of their observations have a " 1 " response. The total within per cent of 69.91 is then the normalised between the weighted average of the within per cent $((4869 \times 80.48)+(2445 \times 48.85) \div 7314)$. Table 5 below depicts the transition probabilities of respondents from one period to the next period. It shows that 87.51 per cent of respondents with a " 0 " response in a given period have a " 0 " response in the next period as well. Similarly, 51.85 per cent of respondents with a " 1 " response in a given period have a " 1 " response in the next period as well. Further, Table 5 indicates that 12.49 per cent of respondents with a " 0 " response in a given period have a " 1 " response in the next period, while 48.15 per cent of respondents with a " 1 " response in a given period have a " 0 " response in the next period.

Regarding the statistics of financial wellbeing, Table 6 shows a transition of 41.83 per cent of respondents from a lower level of financial wellbeing in a given period towards a relatively higher level of financial wellbeing in the next period, as compared to 17.12 per cent of respondents transitioned from a higher level of financial wellbeing in a given period towards a relatively lower level of financial wellbeing in the next period. This trend shows 
a relatively greater percentage of respondents who transitioned towards higher levels of financial wellbeing.

Table 4. Within and between components of debt-taking behaviour and financial wellbeing.

\begin{tabular}{ccccccc}
\hline \multirow{2}{*}{ Variable } & \multirow{2}{*}{ Categories } & \multicolumn{2}{c}{ Overall } & \multicolumn{2}{c}{ Between } & \multicolumn{2}{c}{ Within } \\
\cline { 3 - 6 } & & Frequency & Percent & Frequency & Percent & Percent \\
\hline \multirow{2}{*}{ Debt-taking behaviour } & Do not take on debt (0) & 15,674 & 76.64 & 4869 & 95.23 & 80.48 \\
& Take on debt (1) & 4778 & 23.36 & 2445 & 47.82 & 48.85 \\
\hline \multirow{2}{*}{ Financial wellbeing } & Total & 20,452 & 100.00 & 7314 & 143.05 & 69.91 \\
& Low financial wellbeing (0) & 6644 & 32.49 & 3048 & 59.61 & 54.49 \\
& High financial wellbeing (1) & 13,808 & 67.51 & 4604 & 90.04 & 74.98 \\
\hline & Total & 20,452 & 100.00 & 7652 & 149.66 \\
\hline
\end{tabular}

Table 5. Transition probabilities from one period to the next for debt-taking behaviour.

\begin{tabular}{cccc}
\hline Categories & $\mathbf{0}$ & $\mathbf{1}$ & Total \\
\hline Do not take on debt $(0)$ & 87.51 & 12.49 & 100.00 \\
Take on debt (1) & 48.15 & 51.85 & 100.00 \\
Total & 77.68 & 22.32 & 100.00 \\
\hline
\end{tabular}

Table 6. Transition probabilities from one period to the next for financial wellbeing.

\begin{tabular}{cccc}
\hline Categories & $\mathbf{0}$ & $\mathbf{1}$ & Total \\
\hline Low financial wellbeing (0) & 58.17 & 41.83 & 100.00 \\
High financial wellbeing (1) & 17.12 & 82.88 & 100.00 \\
Total & 30.99 & 69.01 & 100.00 \\
\hline
\end{tabular}

Table 7 displays the results of the two-panel binary logistic regression models. In the first model, the main independent variable, financial wellbeing, is regressed on debt-taking behaviour. The statistically significant AME with a negative sign implies that financial wellbeing has a significant negative association with debt-taking behaviour.

The second model of Table 7 regresses the one-year lagged financial wellbeing on debt-taking behaviour of $t$ time period. The results indicate that the one-year lagged financial wellbeing has a significant negative association with debt-taking behaviour.

"Rho" is the per cent of variation that is explained by the individual-specific effects. A "rho" value close to " 1 " is perceived better for the overall model, while "rho" equal to or near " 0 " indicates that the random-effects regression model is not different from a pooled regression model (Rabe-Hesketh and Skrondal 2008; Tyack and Ščasný 2020). Both the models of Table 7 have a "rho" of more than 0.30, implying that these models are better than a pooled regression model (Rabe-Hesketh and Skrondal 2008). A pooled regression model is a model where the dataset is not declared a panel dataset but run as a simple regression model.

In the next phase of analysis, Table 8 controls the one-year lagged debt-taking behaviour to see if the results of Table 7 are consistent. As Table 8 presents that "rho" is near to zero in both the models, it implies using a pooled regression model instead of a panel regression model. Thus, the results are generated without declaring the dataset as a panel model. In both the models of Table 8, financial wellbeing and the one-year lagged financial wellbeing are negatively significant, respectively. The results imply that financial wellbeing of $t-1$ and $t$ time period is significantly and negatively associated with debt-taking behaviour of $t$ time period, after controlling for the socio-demographic factors and the one-year lagged debt-taking behaviour. The findings meet our objective by demonstrating that improved financial wellbeing reduces the debt-taking behaviour 
of Australians. Furthermore, the interpretation of the AMEs in Table 8 can be read as: the probability of taking on debt decreases by $4.7 \%$ and $2.9 \%$ with a one standard deviation positive change in financial wellbeing and one-year lagged financial wellbeing, respectively.

Table 7. Results of the panel binary logistic random-effects regression model.

\begin{tabular}{ccc}
\hline Variable & Model 1 & Model 2 \\
\hline Financial wellbeing & $-0.048^{* * *}$ & \\
Lag of financial wellbeing & $(0.004)$ & $-0.032^{* * *}$ \\
Age & & $(0.004)$ \\
& 0.000 & $-0.007^{* * *}$ \\
Age-squared & $(0.001)$ & $(0.002)$ \\
& $-0.000^{* * *}$ & -0.000 \\
Female & $(0.000)$ & $(0.000)$ \\
& -0.010 & -0.010 \\
Einimum bachelor's degree & $(0.007)$ & $(0.008)$ \\
& $0.058^{* * *}$ & $0.047^{* * *}$ \\
Employed & $(0.007)$ & $(0.008)$ \\
& $0.093^{* * * *}$ & $0.070^{* * *}$ \\
Married & $(0.008)$ & $(0.009)$ \\
& 0.002 & -0.008 \\
Income & $(0.007)$ & $(0.008)$ \\
& 0.000 & -0.000 \\
Rho & $(0.000)$ & $(0.000)$ \\
& 0.380 & 0.444 \\
Chi-bar-square ${ }^{a}$ & $(0.014)$ & $(0.017)$ \\
Person-years observations & $1014.95^{* * *}$ & $739.77^{* * *}$ \\
Number of persons & 20,452 & 15,339 \\
Average observations per person & 5113 & 5113 \\
\hline
\end{tabular}

Note: ${ }^{* * *} p<0.001$. Debt-taking behaviour is the dependent variable. Average marginal effects (AMEs) are reported in the table. Delta-method standard errors in parentheses. a This is the likelihood ratio test of "Rho".

Table 8. Results of the pooled regression model.

\begin{tabular}{|c|c|c|}
\hline Variable & Model 1 & Model 2 \\
\hline Financial wellbeing & $\begin{array}{c}-0.047^{* * *} \\
(0.004)\end{array}$ & \\
\hline Lag of financial wellbeing & & $\begin{array}{c}-0.029 * * * \\
(0.004)\end{array}$ \\
\hline Lag of debt-taking behaviour & $\begin{array}{c}0.190 * * * \\
(0.005)\end{array}$ & $\begin{array}{c}0.191 * * * \\
(0.005)\end{array}$ \\
\hline Age & $\begin{array}{c}-0.006^{* * *} \\
(0.001)\end{array}$ & $\begin{array}{c}-0.006^{* * *} \\
(0.001)\end{array}$ \\
\hline Age-squared & $\begin{array}{c}-0.000 \\
(0.000)\end{array}$ & $\begin{array}{l}-0.000 \\
(0.000)\end{array}$ \\
\hline Female & $\begin{array}{c}0.001 \\
(0.006)\end{array}$ & $\begin{array}{c}-0.002 \\
(0.006)\end{array}$ \\
\hline Minimum bachelor's degree & $\begin{array}{c}0.032^{* * *} \\
(0.006)\end{array}$ & $\begin{array}{c}0.026^{* * *} \\
(0.006)\end{array}$ \\
\hline Employed & $\begin{array}{c}0.065^{* * *} \\
(0.009)\end{array}$ & $\begin{array}{c}0.061^{* * *} \\
(0.009)\end{array}$ \\
\hline Married & $\begin{array}{l}-0.011 \\
(0.007)\end{array}$ & $\begin{array}{c}-0.016^{*} \\
(0.007)\end{array}$ \\
\hline Income & $\begin{array}{c}0.000 \\
(0.000)\end{array}$ & $\begin{array}{l}-0.000 \\
(0.000)\end{array}$ \\
\hline $\mathrm{Rho}^{\mathrm{a}}$ & $\begin{array}{c}0.093 \\
(0.026)\end{array}$ & $\begin{array}{c}0.093 \\
(0.026)\end{array}$ \\
\hline Chi-bar-square ${ }^{\mathrm{b}}$ & $14.11^{* * *}$ & $14.20 * * *$ \\
\hline Person-years observations & 15,339 & 15,339 \\
\hline Number of persons & 5113 & 5113 \\
\hline Average observations per person & 3 & 3 \\
\hline
\end{tabular}

b This is the likelihood ratio test of "rho". 


\section{Robustness Checks}

For the purpose of checking robustness of the empirical findings of this paper, we chose credit card debt taking behaviour as the dependent variable as used by Tahir et al. (2020). Credit card debt is regarded as one of the problematic types of household debt (Tahir et al. 2020). Furthermore, we employ an unbalanced data from wave 11 to 17 (seven waves) to see if a change in respondents affect the relationship between financial wellbeing and debt-taking behaviour. Table A1 in the appendix section shows the summary statistics, whereas Table A2 displays the results of the panel analysis. As can be seen that financial wellbeing is still negatively associated with debt-taking behaviour, we conclude that our findings are robust.

\section{Discussion}

Financial wellbeing became a focus of research in the first decade of the 21st century (Goyal and Kumar 2021; Riitsalu and Murakas 2019; Sorgente and Lanz 2017; Utkarsh et al. 2020). Financial wellbeing has been defined subjectively (Brüggen et al. 2017; Xue et al. 2019) as well as objectively (Chu et al. 2017; Cifuentes et al. 2016) in the literature. As aligned with the recent research (Brüggen et al. 2017; Utkarsh et al. 2020; Xue et al. 2019), we defined and measured financial wellbeing subjectively. Researchers contend that households' perception of their financial condition is worth considering, as it reflects the level of engagement with their financial matters (Netemeyer et al. 2018). People with similar objective characteristics (such as level of income, assets, and net wealth) may feel differently about their financial conditions (Netemeyer et al. 2018).

A review of the literature highlighted that financial wellbeing is a strong predictor of overall wellbeing (Netemeyer et al. 2018) and a relatively stronger indicator of developed money-management skills, which improve the quality of household financial decisions (Vlaev and Elliott 2014). Given these findings of prior research about financial wellbeing, the aim of this paper was to explore whether improved financial wellbeing has an association with decreased household debt-taking behaviour. We analysed this association using panel analysis of HILDA survey. The empirical results indicated a strong negative relationship between financial wellbeing and debt-taking behaviour. Our robustness analysis also confirmed our main empirical findings. The findings are an extension to the prior research, which posits that higher financial wellbeing levels are associated with lower financial stress (Choi et al. 2020), positive overall wellbeing (Netemeyer et al. 2018), improved quality of life and mental wellbeing (Blanchflower and Oswald 2004), improved health wellbeing (Bridges and Disney 2010), risk-tolerance (Joo and Grable 2004), and positive financial behaviour (Brüggen et al. 2017; Xue et al. 2019).

Our results are comparable to prior relevant research. The empirical results of Ajzerle et al. (2013) showed a positive association between financial capability and debt management. Robb (2011) claimed that people with high financial knowledge exhibit relatively responsible credit card use. Similarly, Brown et al. (2016) found that young consumers with high financial knowledge had decreased debt dependence. Brown and Gray (2016) concluded a negative association of subjective prosperity and financial satisfaction with debt-levels. In an analysis of student data, Solis and Ferguson (2017) found an association between student loans and financial dissatisfaction. Unlike these prior studies, this paper analysed behaviour of households around debt-taking and finds that those with higher levels of financial wellbeing have lower probabilities of taking on debt.

Overall, as an extension to the prior research (Brown and Gray 2016; Xue et al. 2019), our finding implies that a household's positive perception about his/her current and future financial condition along with his/her higher levels of financial satisfaction are associated with a decreased probability to take on debt (Brown and Gray 2016; Donnelly et al. 2012; Garðarsdóttir and Dittmar 2012; Xiao et al. 2006). 


\section{Conclusions, Implications, and Future Research Directions}

The unique contribution of this paper is that it adds to our knowledge that a household's positive perception of his/her personal financial situation can go top of the other factors to have a relevance with the reduced propensity towards undertaking debt. The finding is worthwhile to consider in the Australian context, where household debt is at a record high (ASIC 2017). We suggest policymakers to consider improving Australian households' financial wellbeing. Financial planners and advisors can play a vital role to help households improve their financial wellbeing and financial decisions. As households seek advice from financial planners regarding their financial planning (such as retirement planning and financial contracts commitments), financial planners can assess households' ability to conduct financial tasks as it has a direct connection with improved financial wellbeing (Tahir et al. 2021). Financial planners should encourage their clients to employ the ability of self-control and create proper financial plans. For this purpose, the managing organisations and associations in the financial services industry should organise practical workshops and seminars to spread awareness. The government can also play a role by sponsoring these workshops and seminars to provide financial support in managing these activities. These efforts will serve the purpose of reducing the propensity of households towards undertaking debt (Brown and Gray 2016; Haq et al. 2018; Kolios 2020).

The findings suggest that the policies of financial institutions should be designed, keeping in view the interest of households and under the surveillance of a dedicated department of the state government. Consumer-related policies should be regularly monitored and include flexible terms according to the given financial condition of households. It is one of the responsibilities of the government to ensure that the policies of financial institutions are in the best interest of the public.

Despite several contributions and implications, this paper has limitations, which researchers may wish to address in the future. In this context, the first limitation relates to the items used to measure the constructs of this research. The objective measures of financial wellbeing could produce different findings. Furthermore, a different measure of debt-taking behaviour could produce a different outcome. In addition, other factors related to personal finance, such as financial capability, financial literacy, financial risk-taking attitude etc., can also be relevant to debt-taking behaviour. A panel analysis using these other factors can be helpful to draw interesting conclusions. Moreover, our findings do not show a causal relationship between financial wellbeing and debt-taking behaviour, i-e: increase in financial wellbeing reduces debt-taking behaviour. Instead, we only interpret an association between improved financial wellbeing and reduced debt-taking behaviour. We suggest future research to delve deeper into these concepts and find the causality between financial wellbeing and debt-taking behaviour using relevant theoretical and empirical support. Finally, we acknowledge that our data were collected before the start of the COVID-19 pandemic. Therefore, we recommend future research to replicate this research in post-covid settings to see if similar findings could be generated.

Author Contributions: All authors have contributed to all stages of this research. All authors have read and agreed to the published version of the manuscript.

Funding: We acknowledge that the MDPI exempted us the APC upon request.

Institutional Review Board Statement: Not applicable.

Informed Consent Statement: Not applicable.

Acknowledgments: The authors wish to thank the Editor and the referees for their very fruitful comments and suggestions that led to the improvement of this work.

Conflicts of Interest: The authors declare no conflict of interest.

Data Acknowledgment: This paper uses unit record data from the Household, Income and Labour Dynamics in Australia (HILDA) Survey. The HILDA Project was initiated and is funded by the Australian Government Department of Families, Housing, Community Services and Indigenous 
Affairs (FaHCSIA) and is managed by the Melbourne Institute of Applied Economic and Social Research (Melbourne Institute). The findings and views reported in this paper, however, are those of the author and should not be attributed to either FaHCSIA or the Melbourne Institute.

\section{Appendix A}

Table A1. Summary statistics of the unbalanced panel for a robustness check.

\begin{tabular}{ccccc}
\hline Wave & Frequency & Age & Females & Take on Debt \\
\hline 11 & 7328 & $16-93$ & $52 \%$ & $24.82 \%$ \\
12 & 8033 & $15-95$ & $53 \%$ & $26.15 \%$ \\
13 & 7935 & $16-95$ & $52 \%$ & $25.08 \%$ \\
14 & 7671 & $18-97$ & $52 \%$ & $25.39 \%$ \\
15 & 7897 & $16-98$ & $52 \%$ & $23.63 \%$ \\
16 & 8145 & $15-98$ & $52 \%$ & $22.91 \%$ \\
17 & 8073 & $15-96$ & $52 \%$ & $23.13 \%$ \\
\hline
\end{tabular}

Note: ${ }^{\text {a }}$ The response values for debt-taking behaviour are imputed in wave 14 to be the same as in wave 13.

Table A2. Robustness analysis using the unbalanced panel.

\begin{tabular}{|c|c|c|c|c|}
\hline Variable & Model 1 & Model 2 & Model 3 & Model 4 \\
\hline Financial wellbeing & $\begin{array}{c}-0.084^{* * *} \\
(0.002)\end{array}$ & & $\begin{array}{c}-0.054^{* * *} \\
(0.002)\end{array}$ & \\
\hline Lag of financial wellbeing & & $\begin{array}{c}-0.064^{* * *} \\
(0.003)\end{array}$ & & $\begin{array}{c}-0.036^{* * *} \\
(0.002)\end{array}$ \\
\hline Lag of debt-taking behaviour & & & $\begin{array}{c}0.294^{* * *} \\
(0.002)\end{array}$ & $\begin{array}{c}0.297^{* * *} \\
(0.002)\end{array}$ \\
\hline Age & $\begin{array}{c}0.011^{* * *} \\
(0.001)\end{array}$ & $\begin{array}{c}0.010^{* * *} \\
(0.001)\end{array}$ & $\begin{array}{c}0.001 \\
(0.001)\end{array}$ & $\begin{array}{l}0.001 * \\
(0.001)\end{array}$ \\
\hline Age-squared & $\begin{array}{c}-0.000^{* * *} \\
(0.000)\end{array}$ & $\begin{array}{c}-0.000 * * * \\
(0.000)\end{array}$ & $\begin{array}{c}-0.000^{* * *} \\
(0.000)\end{array}$ & $\begin{array}{c}-0.000^{* * * *} \\
(0.000)\end{array}$ \\
\hline Female & $\begin{array}{c}0.020 * * * \\
(0.006)\end{array}$ & $\begin{array}{l}0.016^{*} \\
(0.006)\end{array}$ & $\begin{array}{c}0.005 \\
(0.003)\end{array}$ & $\begin{array}{c}0.003 \\
(0.003)\end{array}$ \\
\hline Minimum bachelor's degree & $\begin{array}{c}-0.084^{* * *} \\
(0.006)\end{array}$ & $\begin{array}{c}-0.086^{* * *} \\
(0.006)\end{array}$ & $\begin{array}{c}-0.019 * * * \\
(0.003)\end{array}$ & $\begin{array}{c}-0.022^{* * *} \\
(0.003)\end{array}$ \\
\hline Employed & $\begin{array}{c}0.049^{* * *} \\
(0.005)\end{array}$ & $\begin{array}{c}0.041^{* * *} \\
(0.006)\end{array}$ & $\begin{array}{c}0.030^{* * *} \\
(0.004)\end{array}$ & $\begin{array}{c}0.028^{* * *} \\
(0.004)\end{array}$ \\
\hline Married & $\begin{array}{c}-0.013 \text { ** } \\
(0.005)\end{array}$ & $\begin{array}{c}-0.020^{* * *} \\
(0.006)\end{array}$ & $\begin{array}{c}-0.010 \text { * } \\
(0.003)\end{array}$ & $\begin{array}{c}-0.011^{* * *} \\
(0.003)\end{array}$ \\
\hline Income & $\begin{array}{c}-0.000^{* *} \\
(0.000)\end{array}$ & $\begin{array}{c}-0.000^{* * *} \\
(0.000)\end{array}$ & $\begin{array}{l}-0.000 \\
(0.000)\end{array}$ & $\begin{array}{c}-0.000^{* * *} \\
(0.000)\end{array}$ \\
\hline Rho $^{\mathrm{a}}$ & $\begin{array}{c}0.811 \\
(0.005)\end{array}$ & $\begin{array}{c}0.846 \\
(0.005)\end{array}$ & $\begin{array}{c}0.000 \\
(0.000)\end{array}$ & $\begin{array}{c}0.000 \\
(0.000)\end{array}$ \\
\hline Chi-bar-square ${ }^{b}$ & $15000 * * *$ & $11000^{* * *}$ & 0.002 & 0.001 \\
\hline Person-year observations & 55,082 & 39,140 & 39,140 & 39,140 \\
\hline Number of persons & 12,638 & 9963 & 9963 & 9963 \\
\hline Average observations per person & 4.4 & 3.9 & 3.9 & 3.9 \\
\hline \multicolumn{5}{|c|}{$\begin{array}{l}\text { Note: }{ }^{* * *} p<0.001 ;{ }^{* *} p<0.01 ; * p<0.05 \text {. Average marginal effects (AMEs) are reported in the table. Delta-method } \\
\text { standard errors are in parentheses. a A "rho" value of zero or close to zero suggests using a pooled regression } \\
\text { model instead of a panel random-effects regression model. As the "rho" value in the third and fourth model is } \\
\text { zero, the AMEs of these two models are produced using a pooled regression model, whereas the AMEs of the } \\
\text { first and second model are produced using a panel binary logistic random-effects regression model. }{ }^{b} \text { This is the } \\
\text { likelihood ratio test for "rho". }\end{array}$} \\
\hline
\end{tabular}

\section{References}

Ajzerle, Sanja, Mark Brimble, and Brett Freudenberg. 2013. Is financial capability related to the effective use of debt in Australia? Australasian Accounting, Business and Finance Journal 7: 107-26. [CrossRef]

Altfest, Lewis. 2004. Personal financial planning: Origins, developments and a plan for future direction. The American Economist 48: 53-60. [CrossRef]

Ambrey, Christopher L., and Christopher M. Fleming. 2014. Life satisfaction in Australia: Evidence from ten years of the HILDA survey. Social Indicators Research 115: 691-714. [CrossRef] 
ANZ Bank. 2018. Financial Wellbeing-A Survey of Adults in Australia. Available online: https://bluenotes.anz.com/content/dam/ bluenotes/images / financial-wellbeing/ANZ\%20Financial\%20Wellbeing\%20Summary\%20Report\%20-\%20Australia.pdf (accessed on 25 November 2019).

ASIC. 2017. National Financial Literacy Strategy Consultation. Available online: http://www.financialliteracy.gov.au/media/560753 / cp295-national-financial-literacy-strategy-consultation-2017.pdf (accessed on 25 November 2019).

Bell, Andrew, Malcolm Fairbrother, and Kelvyn Jones. 2019. Fixed and random effects models: Making an informed choice. Quality $\mathcal{E}$ Quantity 53: 1051-74. [CrossRef]

Berger, Lawrence M., J. Michael Collins, and Laura Cuesta. 2016. Household debt and adult depressive symptoms in the United States. Journal of Family and Economic Issues 37: 42-57. [CrossRef]

Blanchflower, David G., and Andrew J. Oswald. 2004. Well-being over time in Britain and the USA. Journal of Public Economics 88: 1359-86. [CrossRef]

Bridges, Sarah, and Richard Disney. 2010. Debt and depression. Journal of Health Economics 29: 388-403. [CrossRef] [PubMed]

Brown, Meta, John Grigsby, Wilbert van der Klaauw, Jaya Wen, and Basit Zafar. 2016. Financial education and the debt behavior of the young. The Review of Financial Studies 29: 2490-522. [CrossRef]

Brown, Sarah, and Daniel Gray. 2016. Household finances and well-being in Australia: An empirical analysis of comparison effects. Journal of Economic Psychology 53: 17-36. [CrossRef]

Brüggen, Elisabeth C., Jens Hogreve, Maria Holmlund, Sertan Kabadayi, and Martin Löfgren. 2017. Financial well-being: A conceptualization and research agenda. Journal of Business Research 79: 228-37. [CrossRef]

Campbell, John Y. 2006. Household finance. The Journal of Finance 61: 1553-604. [CrossRef]

Choi, Shinae L., Wookjae Heo, Soo Hyun Cho, and Philseok Lee. 2020. The links between job insecurity, financial well-being and financial stress: A moderated mediation model. International Journal of Consumer Studies 44: 353-60. [CrossRef]

Chu, Zhong, Zhengwei Wang, Jing Jian Xiao, and Weiqiang Zhang. 2017. Financial literacy, portfolio choice and financial well-being. Social Indicators Research 132: 799-820. [CrossRef]

Cifuentes, Myriam Patricia, Nathan J. Doogan, Soledad A. Fernandez, and Eric E. Seiber. 2016. Factors shaping Americans' objective well-being: A systems science approach with network analysis. Journal of Policy Modeling 38: 1018-39. [CrossRef]

Cobb-Clark, Deborah A., and David C. Ribar. 2012. Financial stress, family relationships, and Australian youths' transitions from home and school. Review of Economics of the Household 10: 469-90. [CrossRef]

Cobb-Clark, Deborah A., Sonja C. Kassenboehmer, and Mathias G. Sinning. 2016. Locus of control and savings. Journal of Banking E Finance 73: 113-30. [CrossRef]

Donnelly, Grant, Ravi Iyer, and Ryan T. Howell. 2012. The big five personality traits, material values, and financial well-being of self-described money managers. Journal of Economic Psychology 33: 1129-42. [CrossRef]

Garðarsdóttir, Ragna B., and Helga Dittmar. 2012. The relationship of materialism to debt and financial well-being: The case of Iceland's perceived prosperity. Journal of Economic Psychology 33: 471-81. [CrossRef]

Gerrans, Paul, Cpeelman Speelman, and Guillermo Campitelli. 2014. The relationship between personal financial wellness and financial wellbeing: A structural equation modelling approach. Journal of Family and Economic Issues 35: 145-60. [CrossRef]

Gong, Cathy Honge, and Hal Kendig. 2018. Impacts of voluntary and involuntary workforce transitions at mature ages: Longitudinal evidence from HILDA. Australasian Journal on Ageing 37: 11-16. [CrossRef] [PubMed]

Goyal, Kirti, and Satish Kumar. 2021. Financial literacy: A systematic review and bibliometric analysis. International Journal of Consumer Studies 45: 80-105. [CrossRef]

Hahn, Jinyong, John Ham, and Hyungsik Roger Moon. 2011. Test of random versus fixed effects with small within variation. Economics Letters 112: 293-97. [CrossRef]

Haisken-DeNew, John, David C. Ribar, Christopher Ryan, and Clement Wong. 2019. A Conceptual Framework to Measure Young Australians' Financial Wellbeing. Available online: https:/ / financialcapability.gov.au/files/a-conceptual-framework-to-measureyoung-australians-financial-wellbeing.pdf (accessed on 25 November 2020).

Haq, Wajeeha, Noor Azina Ismail, and NurulHuda Mohd Satar. 2018. Household debt in different age cohorts: A multilevel study. Cogent Economics \& Finance 6: 1455406. [CrossRef]

Hausman, Jerry A. 1978. Specification tests in Econometrics. Econometrica 46: 1251-71. [CrossRef]

Headey, Bruce. 2008. Poverty is low consumption and low wealth, not just low income. Social Indicators Research 89: 23-39. [CrossRef]

Headey, Bruce, and Mark Wooden. 2004. The effects of wealth and income on subjective well-being and ill-being. Economic Record 80: S24-S33. [CrossRef]

Hedges, Larry V., and Jack L. Vevea. 1998. Fixed- and random-effects models in meta-analysis. Psychological Methods 3: 486-504. [CrossRef]

Hunter, John E., and Frank L. Schmidt. 2000. Fixed effects vs. random effects meta-analysis models: Implications for cumulative research knowledge. International Journal of Selection and Assessment 8: 275-92. [CrossRef]

Jarl, Johan, Elizabeth Cantor-Graae, Thida Chak, Ka Sunbaunat, and Charlotte A. Larsson. 2015. Trauma and poor mental health in relation to economic status: The case of Cambodia 35 years later. PLoS ONE 10: e0136410. [CrossRef]

Joo, So-Hyun, and John E. Grable. 2004. An exploratory framework of the determinants of financial satisfaction. Journal of Family and Economic Issues 25: 25-50. [CrossRef] 
Kempson, Elaine, Andrea Finney, and Christian Poppe. 2017. Financial Well-Being: A Conceptual Model and Preliminary Analysis. Norway: Oslo and Akershus University College of Applied Sciences.

Kesavayuth, Dusanee, Joanna Poyago-Theotoky, Dai Binh Tran, and Vasileios Zikos. 2020. Locus of control, health and healthcare utilization. Economic Modelling 86: 227-38. [CrossRef]

Kesavayuth, Dusanee, Kaung Myat Ko, and Vasileios Zikos. 2018. Locus of control and financial risk attitudes. Economic Modelling 72: 122-31. [CrossRef]

Kolios, Bill. 2020. Australian household debt and the macroeconomic environment. Journal of Economic Studies 48: 21-34. [CrossRef]

Kristoffersen, Ingebjørg. 2017. The metrics of subjective wellbeing data: An empirical evaluation of the ordinal and cardinal comparability of life satisfaction scores. Social Indicators Research 130: 845-65. [CrossRef]

Liao, Li, and Jing Jian Xiao. 2014. Consumer finance and social indicators in China. Social Indicators Research 119: 1173-75. [CrossRef]

McKeown, Warren, Mike Kerry, and Marc Olynyk. 2014. Financial Planning, 2nd ed. Brisbane: John Wiley \& Sons.

Meltzer, Howard, Paul Bebbington, T. Brugha, R. Jenkins, S. McManus, and M. S. Dennis. 2010. Personal debt and suicidal ideation. Psychological Medicine 41: 771-78. [CrossRef]

Meng, Xianming, Nam T. Hoang, and Mahinda Siriwardana. 2013. The determinants of Australian household debt: A macro level study. Journal of Asian Economics 29: 80-90. [CrossRef]

Muir, Kristy, Myra Hamilton, J. H. Noone, Axelle Marjolin, Fanny Salignac, and Peter Saunders. 2017. Exploring Financial Wellbeing in the Australian Context. Available online: https://www.arts.unsw.edu.au/sites/default/files/documents/exploring_financial_ wellbeing_australian_context.pdf (accessed on 25 November 2018).

Netemeyer, Richard G., Dee Warmath, Daniel Fernandes, and John G. Lynch Jr. 2018. How am I doing? Perceived financial well-being, its potential antecedents, and its relation to overall well-being. Journal of Consumer Research 45: 68-89. [CrossRef]

Rabe-Hesketh, Sophie, and Anders Skrondal. 2008. Multilevel and Longitudinal Modeling Using Stata, 2nd ed. College Station, Texas: Stata Press.

Reserve Bank of Australia. 2019. Statistical Tables of Household and Business Finances. Available online: https://www.rba.gov.au/ statistics/tables/xls / e02hist.xls (accessed on 25 November 2020).

Richardson, Sue. 2013. A reflection on the household, income and labour dynamics in Australia survey. The Australian Economic Review 46: 216-22. [CrossRef]

Richardson, Thomas, Peter Elliott, and Ronald Roberts. 2013. The relationship between personal unsecured debt and mental and physical health: A systematic review and meta-analysis. Clinical Psychology Review 33: 1148-62. [CrossRef]

Riitsalu, Leonore, and Rein Murakas. 2019. Subjective financial knowledge, prudent behaviour and income: The predictors of financial well-being in Estonia. International Journal of Bank Marketing 37: 934-50. [CrossRef]

Robb, Cliff A. 2011. Financial knowledge and credit card behavior of college students. Journal of Family and Economic Issues 32: 690-98. [CrossRef]

Siahpush, Mohammad, Matt Spittal, and Gopal K. Singh. 2007. Association of smoking cessation with financial stress and material well-being: Results from a prospective study of a population-based national survey. American Journal of Public Health 97: 2281-87. [CrossRef]

Solis, Oscar, and Ralph Ferguson. 2017. The relationship of student loan and credit card debt on financial satisfaction of college students. College Student Journal 51: 329-36.

Sorgente, Angela, and Margherita Lanz. 2017. Emerging adults' financial well-being: A scoping review. Adolescent Research Review 2: 255-92. [CrossRef]

Summerfield, Michelle, Sarah Bright, Markus Hahn, Nathan La, Ninette Macalalad, Nicole Watson, Roger Wilkins, and Mark Wooden. 2019. HILDA User Manual_Release 18. Melbourne: Melbourne Institute of Applied Economic and Social Research, University of Melbourne, Available online: https:/ / melbourneinstitute.unimelb.edu.au/_data/assets/pdf_file/0008/3247289/HILDAUser-Manual-Release-18.0.pdf (accessed on 25 November 2020).

Sweet, Elizabeth, Arijit Nandi, Emma K. Adam, and Thomas W. McDade. 2013. The high price of debt: Household financial debt and its impact on mental and physical health. Social Science \& Medicine 91: 94-100. [CrossRef]

Tahir, Muhammad Sheikh, Abdullahi Dahir Ahmed, and Daniel William Richards. 2021. Financial literacy and financial well-being of Australian consumers: A moderated mediation model of impulsivity and financial capability. International Journal of Bank Marketing. [CrossRef]

Tahir, Muhammad Sheikh, Daniel William Richards, and Abdullahi Dahir Ahmed. 2020. Financial literacy, attitudes, and financial satisfaction: An assessment of credit card debt-taking behavior of Australians. Financial Services Review 28: $273-301$.

Turunen, Elina, and Heikki Hiilamo. 2014. Health effects of indebtedness: A systematic review. BMC Public Health 14: 489. [CrossRef]

Tyack, Nicholas, and Milan Ščasný. 2020. 'Warehouse' or research centre? Analyzing public preferences for conservation, pre-breeding and characterization activities at the Czech genebank. Food Security. [CrossRef]

Utkarsh, Asheesh Pandey, Arvind Ashta, Eli Spiegelman, and Angela Sutan. 2020. Catch them young: Impact of financial socialization, financial literacy and attitude towards money on financial well-being of young adults. International Journal of Consumer Studies 44: 531-541. [CrossRef]

Vlaev, Ivo, and Antony Elliott. 2014. Financial well-being components. Social Indicators Research 118: 1103-23. [CrossRef]

West, Tracey, and Andrew C. Worthington. 2019. The impact of major life events on household asset portfolio rebalancing. Studies in Economics and Finance 36: 334-47. [CrossRef] 
Wilkins, Roger, and Mark Wooden. 2009. Household debt in Australia: The looming crisis that isn't. The Australian Economic Review 42: 358-66. [CrossRef]

Wilkins, Roger. 2016. The HILDA survey: What's in it for finance researchers and practitioners? JASSA The Finsia Journal of Applied Finance 3: 6-13.

Wooden, Mark, and Nicole Watson. 2007. The HILDA survey and its contribution to economic and social research (so far)*. Economic Record 83: 208-31. [CrossRef]

Wooden, Mark, Simon Freidin, and Nicole Watson. 2002. The household, income and labour dynamics in Australia (HILDA) survey: Wave 1. The Australian Economic Review 35: 339-48. [CrossRef]

Xiao, Jing Jian, and Barbara O'Neill. 2018. Propensity to plan, financial capability, and financial satisfaction. International Journal of Consumer Studies 42: 501-12. [CrossRef]

Xiao, Jing Jian, Benoit Sorhaindo, and E. Thomas Garman. 2006. Financial behaviours of consumers in credit counselling. International Journal of Consumer Studies 30: 108-21. [CrossRef]

Xue, Rui, Adrian Gepp, Terry J. O'Neill, Steven Stern, and Bruce J. Vanstone. 2019. Financial well-being amongst elderly Australians: The role of consumption patterns and financial literacy. Accounting and Finance 60: 4361-86. [CrossRef] 